\title{
Epimenides z Krety w kontekście nowotestamentowym (Tt 1,12; Dz 17,28)
}

\author{
Epimenides of Crete in the New Testament Context (Titus 1:12; Acts 17:28)
}

\author{
PIOTR LOREK \\ Ewangelikalna Wyższa Szkoła Teologiczna we Wrocławiu \\ p.lorek@ewst.edu.pl, ORCID: 0000-0003-4345-5235
}

\begin{abstract}
Streszczenie: W artykule przybliżona zostaje postać starożytnego mędrca greckiego Epimenidesa z Krety. Przywoływane są wybrane dzieła starożytnej literatury pozabiblijnej odnoszące się do Epimenidesa. Następnie uzyskane dane zestawiane są z dwoma fragmentami nowotestamentowymi (w szczególności z Tt 1,12, a także pokrótce z Dz 17,28). W ten sposób wydobyte zostaje specyficzne wykorzystanie postaci Epimenidesa w biblijnych urywkach. Dostrzec można powoływanie się na autorytet Epimenidesa, jednakże bez uwzględnienia pierwotnego kontekstu jego słów. Ciekawe jest także uchwycenie trudności interpretacyjnych u wybranych komentatorów chrześcijańskich żyjących na przełomie IV i V w. n.e., dostrzegających apologetyczne trudności wynikające z cytowania Epimenidesa w Tt 1,12.

Słowa kluczowe: Epimenides z Krety, Nowy Testament, Tt 1,12, Dz 17,28

Abstract: This paper introduces the figure of the ancient Greek sage, Epimenides of Crete. Some of the works of ancient extra-biblical literature referring to Epimenides are cited. Next, the data obtained are compared with two New Testament passages (in particular Titus 1:12 and also briefly Acts 17:28). In this way, the specific use of the figure of Epimenides in the biblical fragments is shown. One can see the reference to the authority of Epimenides, however, without considering the original context of his words. It is also interesting to capture the difficulties of interpretation in selected Christian commentators living at the turn of the 4th and 5th centuries, who perceive the apologetic difficulties resulting from the quotation of Epimenides in Titus 1:12.
\end{abstract}

Keywords: Epimenides of Crete, New Testament, Titus 1:12; Acts 17:28

W deuteropawłowym Liście do Tytusa autor wspomina o pewnym anonimowym

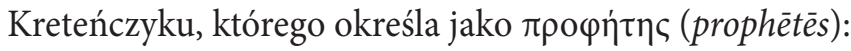

(10) Wielu bowiem jest niekarnych, pustych gadułów, zwodzicieli, zwłaszcza pośród tych, którzy są obrzezani; (11) tym trzeba zatkać usta, gdyż oni to całe domy wywracają, nauczając dla niegodziwego zysku, czego nie należy. (12) Jeden z nich, ich własny wieszcz

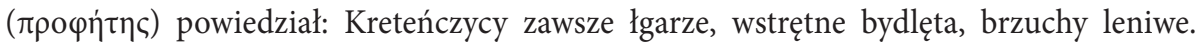
(13) Świadectwo to jest prawdziwe, dla tej też przyczyny karć ich surowo, ażeby ozdrowieli w wierze (14) i nie słuchali żydowskich baśni i nakazów ludzi, którzy się odwracają od prawdy. (15) Dla czystych wszystko jest czyste, a dla pokalanych i niewierzących nic nie jest czyste, ale pokalane są zarówno ich umysł, jak i sumienie. (16) Utrzymują, że znają 


\section{PIOTR LOREK}

Boga, ale uczynkami swymi zapierają się go, bo to ludzie obrzydliwi i nieposłuszni, i do żadnego dobrego uczynku nieskłonni (Tt 1,10-16; Biblia Warszawska [BW]).

Według świadectwa Klemensa Aleksandryjskiego, żyjącego na przełomie II i III w., które zawartł w dziele Kobierce, dowiadujemy się, że ów anonimowy

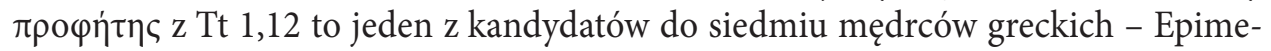
nides (VII-VI w. p.n.e.):

Co do siódmego [mędrca], to jedni wymieniali Periandra z Koryntu, inni Anacharsisa ze Scytii. Inni jeszcze Epimenidesa z Krety, o którym wspomina apostoł Paweł jako o proroku helleńskim tak mówiąc w Liście do Tytusa: Powiedział jeden z nich, ich własny wieszcz: «Krety mieszkańcy zawsze kłamliwi, złe bestie i pasibrzuchy» - i jest to świadectwo prawdziwe [kursywa dodana ${ }^{1}$.

Klemens w swoim komentarzu zauważa pozytywne odniesienie się autora Listu do Tytusa do proroków pogańskich: „Widzisz więc, że trochę prawdy przyznaje on także wieszczom helleńskim, przemawiając ku zbudowaniu kogoś lub zawstydze-

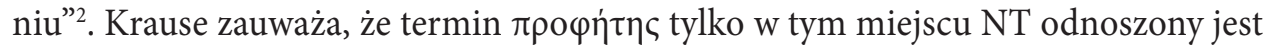
do nieżydowskiej i niechrześcijańskiej osoby ${ }^{3}$.

Niniejsza praca stawia sobie za cel przybliżenie postaci Epimenidesa w wybranych dziełach starożytnej literatury niebiblijnej, a następnie odniesienie zebranych informacji o niej do kontekstu fragmentu z Tt 1,12 i Dz 17,28. Pozwoli to na ukazanie specyficznego wykorzystania słów Epimenidesa w biblijnym kontekście, a także wskaże na obronną reakcję wybranych starożytnych komentatorów chrześcijańskich na pozytywne wykorzystanie przez autora Listu do Tytusa postaci pogańskiego proroka.

\section{Epimenides z Krety w starożytnej literaturze pozabiblijnej}

Platon (V/IV w. p.n.e.) w pierwszej księdze Praw wspomina o Epimenidesie jako o proroku i kapłanie, który „miał się przyjaźnić z Solonem i z rozkazu boga oczyścić

1 Clemens Alexandrinus, Stromata I, XIV, 59 (Niemirska-Pliszczyńska, 45). Teodoret z Cyru uważa, że Tt 1,12 nawiązuje do Kallimacha; por. Theodoretus Cyrensis, Ad Romanos, ŹMT 20, 187. Craig Keener (The IVP Bible Commentary, 636) widzi to następująco: „The saying Paul quotes here [Tt 1,12] has been attributed to several sources, the earliest being the sixth-century B.C. teacher Epimenides of Knossos in Crete. [...] The real source may more likely by Hesiod by way of the third-century B.C. Callimachus's Hymn to Zeus".

2 Clemens Alexandrinus, Stromata I, XIV, 59.

3 Mark S. Krause („Crete”) stwierdza: „The description of this writer as a 'prophet' ( might be the only place where a non-Hebrew or non-Christian is referred to this way in the New Testament". 
Ateny ze zmazy krwi przelanej podczas zamachu Kylona oraz uwolnić je od zarazy w r. 596":

[...] tu urodził się Epimenides, mąż boży, spowinowacony był z nami. Na dziesięć lat przed wojnami perskimi udał się on do was, posłuszny wyroczni boga i nakazane przez boga złożył ofiary. I gdy Ateńczycy obawiali się najazdu Persów, on im przepowiedział, że nie przybędą przed upływem dziesięciu lat, a skoro nadciągną, nie uczynią nic z tego, co zamyślają, i zawrócą doznawszy więcej strat, niż ich wyrządzą̧

Arystoteles (IV w. p.n.e.) w Retoryce (III.17) powołuje się na Epimenidesa, twierdząc, że ten nie zajmował się przepowiadaniem przyszłości, ale dawał wgląd w wydarzenia z przeszłości:

Wymowa polityczna jest sztuką trudniejszą od wymowy sądowej i nie bez powodu; dotyczy ona przecież przyszłości, wymowa sądowa natomiast przeszłości, którą znają nawet wróżbici, jak to powiedział Epimenides z Krety. On sam nie przepowiadał zresztą tego, co ma się stać, ale mówił o tym, co się już stało, ale pozostaje ciągle niewyjaśnione ${ }^{6}$.

Henryk Podbielski dodaje do tego fragmentu uwagę, w której komentuje wieszczy dar Epimenidesa:

Epimenides z Krety (VII - VI w.), cudotwórca i wieszczek; uważano, że pozostawał w szczególnych kontaktach ze światem bogów, a dar wieszczenia, jaki przypisują mu niektóre legendy, był, jak stwierdza Arystoteles, sztuką wysnuwania wniosków o przyszłości na podstawie analizy wydarzeń minionych?

Arystoteles wspomina Epimenidesa także w swoim dziele Ustrój polityczny Aten $(\mathrm{A}, 1)$, nawiązując do wydarzenia oczyszczenia tego miasta: „Epimenides z Krety oczyścił potem miasto od zmazy".

Grecki geograf Strabon, żyjący w I w. p.n.e., w Geographica (X.4,14), opisując Kretę, wzmiankuje o pochodzeniu Epimenidesa: „Z Fajstos - jak mówią - pochodził Epimenides, który czynił oczyszczenia za pomocą wierszy"'.

4 Plato, De Legibus (Maykowska, przyp. 8 tłumacza, 524).

5 Plato, De Legibus (Maykowska, 41).

6 Aristotelis, Ars Rhetorica (Podbielski, 215).

7 Aristotelis, Ars Rhetorica (Podbielski, przyp. 250). Krause („Crete”) zauważa: „Aristotle describes Epime-

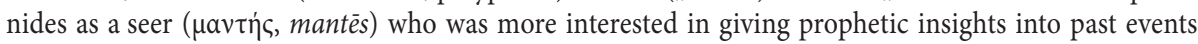
than in predicting the future (Aristotle, Rhetoric 3.17.10). This description suggests that Epimenides was a social and cultural critic, perhaps explaining his biting criticism of his own people in Paul's quote".

8 Aristotelis, Atheniensium Respublica.

9 Strabo, Geographica (Kaczyńska -Witczak, 223-232). Tłumacze dzieła Strabona wspominają o alternatywnym miejscu pochodzenia Epimenidesa, mianowicie o mieście Knossos: „Epimenides z Krety, poeta, 


\section{PIOTR LOREK}

Jak wskazują powyżej cytowane słowa Platona, Arystotelesa i Strabona, Epimenides został zapamiętany przez starożytnych głównie z powodu pomocy, jakiej udzielił Ateńczykom, oczyszczając ich miasto od zarazy. W rozdziale dotyczącym Solona (par. 12) Plutarch z Cheronei (I/II w. n.e.), grecki historyk tworzący w czasie zbieżnym z nowotestamentowym, w Żywotach sławnych mężów także wspomina Epimenidesa w kontekście oczyszczenia Aten:

Wśród tych rozruchów napadli na Ateńczyków Megarejczycy i Ateńczycy utracili Nisaję i znów zostali wypędzeni z Salaminy. Miasto ogarnęly jakieś strachy wynikające z przesądów i dziwnych zjawisk, a wieszczkowie mówili, że najwyraźniej zbrodnie i splamieni nimi wymagają oczyszczenia przez odpowiednie ofiary.

Posłano więc po Kreteńczyka Epimenidesa z Fajstosu, którego niektórzy umieszczają między siedmiu mędrcami zamiast Periandra. Wydał się bogom miły i biegły w sprawach boskich mądrością wyższego natchnienia i wtajemniczenia. Dlatego nazywano go wówczas także synem nimfy Blasty i nowym Kuretem. Ten przybywszy zaprzyjaźnił się z Solonem i wielkie mu oddał usługi wskazując drogę do prawodawstwa. Sprawił, że ludzie stali się przyzwoitsi wobec praktyk kultowych i spokojniejsi w niepowodzeniach, odprawił zaraz pewne ofiary przeciw zmartwieniom, odjął ludziom barbarzyńską surowość, której się dotąd trzymała przeważająca część kobiet. I co najważniejsze - przez przebłagalne modły i oczyszczające praktyki, i święte budowle, uzdrowił i uświęcił miasto, czyniąc je posłusznym wobec sprawiedliwego prawa i łatwiej dającym się przekonać do zgody.

Odwiedzając Munychię i przez dłuższy czas ją obserwując miał też Epimenides powiedzieć: «Jak ślepy jest człowiek wobec przyszłości! Ateńczycy własnymi zębami by pożarli to miasto, gdyby wiedzieli, ile nieszczęścia przyczyni ich miastu to miejsce».

Podobnie Tales miał wypowiedzieć słowa przeczucia. Kazał się po śmierci pogrzebać w pewnym zacisznym i niepostrzegalnym miejscu ziemi milezyjskiej, przepowiadając, że to miejsce będzie kiedyś agorą Miletu.

Epimenides zaś wśród pełni uwielbienia dla niego odjechał niczego nie żądając od Aten, prócz gałązki świętej oliwki, i tę zabrał ze sobą, choć ofiarowano mu wiele bogatych darów i wielkich zaszczytów ${ }^{10}$.

Historia oczyszczenia Aten obecna jest także u żyjącego w pierwszej połowie III w. n.e. Diogenesa Laertiosa. Poniższe słowa pochodzą z dzieła Laertiosa Żywoty i poglądy stynnych filozofów (1, 10 Epimenides):

prorok i cudotwórca, żyjący w VI wieku p.n.e. Mówiono o nim, że przespał 75 lat w Jaskini Idajskiej, a w czasie snu porozumiewał się z Dzeusem. Przypisywano mu szereg cudownych działań, m.in. oczyszczenie Attyki od zarazy w roku 596 p.n.e. Postać i działalność Epimenidesa prezentuje W. Appel, Epimenides, „Filomata” 362, 1984, s. 221-230, który w przeciwieństwie do Strabona twierdzi, że Epimenides był «rodem z kreteńskiego miasta Knossos»" (ibidem, 221). 
[...] gdy Ateny zostały dotknięte zarazą i Pytia orzekła, że miasto powinno złożyć oczyszczającą ofiarę, wysłano okręt oraz Nikiasza, syna Nikeratosa, na Kretę, z zaproszeniem dla Epimenidesa. On to w czasie czterdziestej szóstej Olimpiady [596-593 p.n.e.] udał się do Aten, oczyścił miasto i stłumił zarazę w następujący sposób. Wziąwszy białe i czarne owce zapędził je na wzgórze Areopagu, a stamtąd pozwolił im iść, gdzie chciały. Jednocześnie nakazał tym, którzy owce pędzili, aby zabijali je w ofierze miejscowemu bogu tam, gdzie każda z nich się położyła. W ten sposób uśmierzono zło. Dlatego dotychczas jeszcze można znaleźć bezimienne ołtarze po wsiach attyckich - to pamiątki złożonego wówczas zadośćuczynienia. Wedle innych podań przyczyną zarazy była zbrodnia Kylońska. Podania wymieniają także sposób, w jaki ją odpokutowano. Dwaj młodzieńcy, Kratinos i Ktezibios, musieli umrzeć, ażeby odwrócić zarazę. Ateńczycy uchwalili, że dadzą Epimenidesowi w upominku jeden talent oraz okręt, który miał go odwieźć na Kretę. On jednak nie przyjął pieniędzy, ale doprowadził do traktatu przyjaźni i przymierza między Knossos i Atenami. W krótkim czasie po powrocie do domu Epimenides umarł, jak opowiada Flegon w księdze O długowieczności, przeżywszy sto pięćdziesiąt siedem lat. Według Kreteńczyków zaś brakowało mu jednego roku do trzystu lat. Ksenofanes z Kolofonu podaje, że słyszał, iż Epimenides żył sto pięćdziesiąt cztery lata ${ }^{11}$.

Pozabiblijne świadectwa starożytne przedstawiają Epimenidesa jako wieszcza będącego w szczególnej więzi z bogami pogańskimi, a nawet jako samego boga. Przywołajmy w tym kontekście jeszcze jeden fragment z Diogenesa Laertiosa:

Demetrios opowiada, że według niektórych historyków Epimenides otrzymał od Nimf nieznany pokarm, który przechowywał w racicy wołu. Zażywał go w małych dawkach i nie miał w ogóle nigdy wypróżnień; nikt też nie widział, aby kiedykolwiek jadł. Wspomina o tym także Timaios w drugiej księdze [Historii Sycylii]. Niektórzy opowiadają, że Kreteńczycy składali mu ofiary jako bogu. Mówią również, że miał nadzwyczajne zdolności przepowiadania przyszłości. Widząc Munichię powiedział, że Ateńczycy nie przypuszczają nawet, jak wielkich nieszczęść przyczyną będzie dla nich ten port; gdyby wiedzieli, roznieśliby go choćby własnymi zębami. Zapowiedział im to dużo wcześniej, zanim się to stało. Według podania on pierwszy nazwał się Ajakosem i przepowiedział Lacedemończykom, że zostaną pokonani przez Arkadyjczyków. Utrzymywał, że przechodził przez wiele wcieleń. Teopompos podaje w Osobliwościach, że gdy Epimenides budował świątynię Nimf, usłyszał głos z nieba: «Epimenidesie, nie dla Nimf, ale dla Zeusa buduj». Kreteńczykom

11 Diogenis Laertii, De Vitis (Krońska, 67). Por. też: „Wydaje się, że ani moje prawa nie miały przynieść Ateńczykom bardzo wielkiego pożytku, ani ty, oczyszczając miasto, niewiele mu pomogłeś" (Krońska, 42). Por. też: „Epimenides zestarzał się w ciągu tylu dni, ile lat przespał. Mówi o tym Teopompos. Myronianos mówi w Paralelach, że Kreteńczycy uważali go za jednego z Kuretów. Ciało jego Lacedemończycy przechowują u siebie zgodnie z pewną wyrocznią, jak podaje Sosibios Lakończyk" (Krońska, 70). 


\section{PIOTR LOREK}

przepowiedział klęskę Lacedemończyków w wojnie z Arkadyjczykami, jakeśmy to już mówili. Zostali oni pokonani pod Orchomenos ${ }^{12}$.

Diogenes przywołuje także historię, która sprawiła, że został uznany za „ulubieńca bogów":

Epimenides był, według Teopomposa i wielu innych, synem Faistiosa, według innych synem Dozjadesa, a według jeszcze innych synem Agezarcha. Pochodził z Knossos na Krecie, jakkolwiek na Kreteńczyka nie wyglądał, bo nosił długie włosy. Wysłany raz przez ojca, aby paść trzodę, koło południa zmylił drogę i w jakiejś jaskini przespał pięćdziesiąt siedem lat. Obudziwszy się szukał swojej trzody, przekonany, że przed chwilą zasnął. Gdy jej nie znalazł, pobiegł znów na pastwisko, ale widząc, że wszystko tam już się zmieniło i że jest inny właściciel, podążył do miasta, wszedł do swego domu, gdzie zastał obcych ludzi, którzy go pytali, kim jest, wreszcie znalazł swego młodszego brata, już także starca, i od niego dowiedział się całej prawdy. Stał się przez to sławny w Grecji i uznano go za ulubieńca bogów ${ }^{13}$.

Diogenes wspomina także o piśmiennictwie Epimenidesa oraz jego praktykach:

Epimenides napisał poemat $O$ narodzinach Kuretów i Korybantów i Teogonią łącznie około pięciu tysięcy wierszy; oraz O budowie okrętu Argos i Wyprawe Jazona do Kolchidy, około pięciu tysięcy sześciuset wierszy. Pisał także prozą O składaniu ofiar i O ustroju politycznym Krety, a także O Minosie i Radamantysie, około czterech tysięcy wierszy. Ateńczykom wybudował świątynię Eumenid, jak mówi Lobon z Argos w piśmie O poetach. Podobno Epimenides pierwszy stosował oczyszczanie sakralne ziemi i domów oraz budował świątynie. Niektórzy zaś opowiadają, że nigdy nie sypiał, a część nocy spędzał na zbieraniu korzeni ${ }^{14}$.

\section{Epimenides z Krety i kłamstwo jego rodaków poza kontekstem biblijnym}

Współcześnie Epimenides znany jest głównie z tzw. paradoksu kłamcy. Według Tt 1,12 on sam jako Kreteńczyk twierdzi, że Kreteńczycy to kłamcy. Czy mówi zatem prawdę, skoro sam jest Kreteńczykiem? Należy zauważyć, że Epimenides w tej wypowiedzi nie formułuje paradoksu kłamcy. Brak w niej choćby dużego kwantyfikatora nakazującego myśleć, że wszyscy Kreteńczycy są kłamcami. O co więc chodziło

\footnotetext{
12 Diogenis Laertii, De Vitis (Krońska, 69-70).

13 Diogenis Laertii, De Vitis (Krońska, 66-67).

14 Diogenis Laertii, De Vitis (Krońska, 68).
} 
Epimenidesowi w tej wypowiedzi, wyglądającej na brutalną inwektywę wymierzoną przeciwko swoim rodakom, dla których miał być wręcz bogiem?

Rozumiejąc jego słowa „zawsze łgarze, wstrętne bydlęta, brzuchy leniwe” ogólnie, należałoby je potraktować właśnie jako zwykłe obelgi. Epimenides mówiłby wtedy ogólnie o Kreteńczykach (por. współczesny czasownik „cyganić”). Miałby przyrównywać ich do zwierząt (por. współczesne inwektywy „osła” czy „świni”). Wreszcie, w trzeciej frazie, miałby uogólniać jedną z negatywnych cech - lenistwo - i przypisywać ją Kreteńczykom (por. współczesny termin „wandalizm”, nawiązujący do Wandali, starożytnego plemienia germańskiego, które zniszczyło Rzym).

Dla starożytnych rzeczywiście Kreteńczycy mogli kojarzyć się z kłamstwem ${ }^{15}$, ale powodem miało być konkretne kłamstwo powiązane z ich wierzeniami religijnymi.

Brytyjski biblista James Rendel Harris, żyjący na przełomie XIX i XX w., w cyklu trzech artykułów na łamach The Expositor ${ }^{16}$ zaproponował rekonstrukcję fragmentu z niezachowanego pisma Epimenidesa. Do rekonstrukcji wykorzystał napisany w języku syryjskim manuskrypt Iszodada z Merw (IX w. n.e.), będący komentarzem do Dziejów Apostolskich, zawierającym tradycję pochodzącą od Teodora z Mopswestii (350-428). Komentarz Iszodada brzmi następująco:

Te zdania: «W Nim żyjemy i ruszamy się, i istniejemy» oraz «Jak niektórzy z waszych mędrców [sic!] powiedzieli: Z jego rodu jesteśmy» - Paweł zaczerpnął z poetów pogańskich. Najpierw, co się tyczy owego «W Nim żyjemy» itd.: Otóż Kreteńczycy istotnie głosili o Zeusie, iż był on władcą, a potem został rozszarpany przez dzika i pogrzebany. I - powiadali - jest u nas jego grób. Przeto Minos, syn Zeusowy, ułożył na cześć swego ojca mowę pochwalną; i w niej tak rzekł: «Kreteńczycy wykuwają grób dla Ciebie, o, Święty i Wzniosły! Kłamcy, złe bestie, brzuchy leniwe! Bo przecież Ty nie umarłeś na zawsze, Ty jesteś żywy: w Tobie bowiem żyjemy, ruszamy się i istniejemy». - Tak więc błogosławiony Paweł zaczerpnął to zdanie od Minosa. A to drugie: «Jesteśmy z rodu Boga» - wziął z poety Aratosa, który pisał o Bogu oraz o siedmiu [planetach] i dwunastu [znakach Zodiaku], powiadając: «Od Boga zaczynamy, od Pana Niebios, to znaczy - od Zeusa. Albowiem wszystkie rynki, morza i nieba napełnione są Jego imieniem. I na każdym miejscu wszyscy Go potrzebujemy, z Jego bowiem rodu jesteśmy. A On w łaskawości swej daje dobre znaki nam i wszystkim ludziom. Pobudza nas, abyśmy wyszli do pracy. Zarządza wszystkim, co wi-

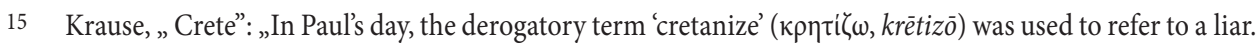
For example, in The Life of Lysander, Plutarch (late first-early second century ad) uses the expression 'cretanize a Cretan' to describe Lysander using a Cretan (or liar) to lie for him (Life of Lysander 20.2).

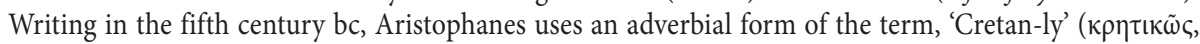
$k r e \bar{t} i k \bar{s} s$ ), in what seems to be a reference to acting in a two-faced manner (Aristophanes, Ecclesiazusae, 1165). The Cretans' claim that Crete was the site of Zeus' grave might have contributed to their reputation as liars, since the idea of a gravesite for an immortal god was contradictory".

16 Harris, „The Cretans Always Liars”, 305-317; Harris, „A Further Note on the Cretans”, 332-337; Harris, „St. Paul and Epimenides”, 348-353. 


\section{PIOTR LOREK}

dzialne i co niewidzialne. Dlatego wszyscy czcimy Go i powiadamy: Bądź pozdrowiony, nasz Ojcze, cudowny i wielki!» ${ }^{17}$

\section{Zaproponowana przez Harrisa rekonstrukcja fragmentu dzieła Epimenidesa} brzmi następująco:

Ukształtowany został grobowiec dla Ciebie, jedyny święty i potężny.

Kreteńczycy zawsze kłamcy, wstrętne bestie, brzuchy bezczynne.

Ale nie jesteś martwy: żyjesz i będziesz trwać na zawsze,

$\mathrm{W}$ tobie żyjemy, poruszamy się i jesteśmy ${ }^{18}$.

W tym fragmencie Minos, mityczny król Krety, syn Zeusa i Europy, zwraca się do Zeusa. Wbrew przekonaniom Kreteńczyków wyznaje nieśmiertelność swojego boskiego ojca. Widać w tym zrekonstruowanym fragmencie nie tylko nawiązanie do Tt 1,12, ale także do Dz 17,28.

Według Harrisa Kreteńczycy wierzyli, że Zeus, podobnie jak i w innych kultach, został zabity przez dzikiego niedźwiedzia. Kreteńczycy zaś podczas sprawowanego kultu mieli spożywać surowe mięso zwierzęcia reprezentującego samego boga ${ }^{19}$. Stąd

17 Cytuję za: Dąbrowski, „Cytaty z Aratosa i Epimenidesa”, 546-547, z oryginalnymi nawiasami kwadratowymi. Dąbrowski korzysta z: M.D. Gibson, The Commentaries of Ishodad of Merv, Bishop of Hadatha. IV. Acts of Apostles with an introduction by J. Rendel Haris (Horae Simiticae 10; Cambridge: University Press 1913).

18 Polskie tł. za: Kalinowski, Dlaczego Jezus cytował Pawłowi. Tekst zrekonstruowany przez Jamesa R. Harrisa miał wyglądać następująco:

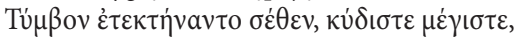

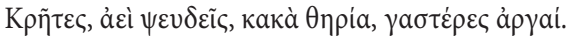

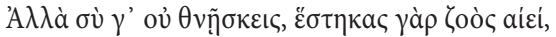

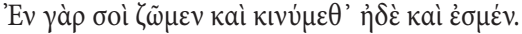

19 Harris, "A Further Note on the Cretans”, 333-334: „Much support was found for this theory in a statement, which was suspected to have come down through Theodor of Mopsuestia, that the Cretan Zeus had been killed by a wild boar, exactly as in the story of Adonis, and, as has been suspected, in the story of Attis: and, in confirmation, it was pointed out that the Cretans of Praesos had a ritual in which the pig was a prominent feature, which may well have been due to the animal being the representative or equivalent of the deity, as the modern school explain the wild boar of the Adonis legends".

"If we are right in our supposition that the attack on the Cretan liars was due, in the first instance, to the famous Cretan lie, it will follow that it is reasonable to refer the rest of the strong language of Epimenides to the same source. For why should we introduce the theory of general Cretan villainy into the argument, when the first clause of the indictment has become a particular offence. We are, then, bound to try for an explanation of the 'evil beasts and lazy gluttons' which shall be consistent with the assumed cult of a Cretan deity of the type of Dionysos, Attis, and Adonis. What was there especially beastly or ravenous about the Cretan cult? Obviously we have here some allusion to the sacrifices offered and partaken of. Now bearing in mind that the cult-animal is the substitute for the god and the means of communion with him, and that in cases like that of Adonis, where the god is said to have been destroyed by the animal, the result to which anthropologists come is that the god was primitively the animal, or at least the animal was his representative, and that the god was actually eaten in the form of the animal, the suggestion naturally arises that something similar has occurred in the supposed Zeus-cult of Crete. Here also we have 
też miało występować u Epimenidesa powiązanie zawarte w Tt 1,12 między kłamstwem (o śmierci Zeusa i jego grobie na Krecie) oraz zwierzętami i brzuchami (rozumianymi jako kultyczne zjadanie boskiego zwierzęcia) ${ }^{20}$.

Historia Zeusa i jego powiązanie z Kretą jest szersze i nie dotyczy tylko jego domniemanej śmierci na tej wyspie. Otóż według mitologicznych podań Rea, matka Zeusa, chcąc uchronić swojego syna przed pożarciem przez jego własnego ojca Kronosa, miała uciec na Kretę, tam po kryjomu urodzić Zeusa w grocie jednej z gór (Dikte lub Ida $)^{21}$. Pierwsze linie Hymnu o Zeusie poety aleksandryjskiego Kallimacha z Cyreny (IV-III w. p.n.e.) nawiązują zarówno do urodzin, jak i śmierci Zeusa na Krecie:

W chwili ofiary dla Zeusa czyż lepszy temat wynika,

Niźli sławić wielkiego, wiecznego władzy sternika,

Boga samego, tytanów pogromcę, sędziego na niebie?

Zeusie, jestem w rozterce, jak sławić wypada mi ciebie:

Jak lykiejskiego czy diktejskiego? Wszak toczą się spory.

Zeusie, jedni stwierdzają, żeś rodem z idajskiej jest góry,

Drudzy, żeś rodem z Arkadii. Którzy więc, Ojcze, skłamali?

«Znani są kłamcy na Krecie». Toć oni grób usypali

Tobie, o Panie! Ty zaś nie zmarłeś, ty wieczne masz życie! 22

the death of the deity by means of a wild-boar and the occurrence of a pig in the sacrifices. My suggestion, then, is that the early Cretans ate their deity sacramentally under the form of a pig: and I further conjecture that, as in so many similar cults, they ate the animal raw. This would at once explain why Epimenides called them not only liars, but also beasts and gluttons" (ibidem, 336-337).

Harris ("St. Paul and Epimenides”, 350) podsumowuje swoje badania: „A further attempt was made to show that the whole of the vituperation of the Cretans in the second line is due to a single cause, the death and burial of Zeus, and that the comparison with the beast and the glutton was due to the fact that, as in similar cults, they ate their god in the form of the sacred animal and ate him raw".

20 Jerome D. Quinn (The Letter to Titus, 107-109) uważa, że nawiązanie zawarte w Tt 1,12 funkcjonowało jako powiedzenie, przez co nie rekonstruuje jego pierwotnego kontekstu. Stąd np. stwierdzenie o „wstrętnych bydlętach" z Tt 1,12 odnosi do powszechnej opinii starożytnych o tym, że na Krecie nie było groźnych dzikich zwierząt (por. ibidem, 108). Por. także Collins, I \& II Timothy and Titus, 334. Gordon D. Fee (1 and 2 Timothy, Titus, 179) dostrzega związek między oskarżeniem Kreteńczyków o kłamstwo a ich twierdzeniem o istniejącym grobie Zeusa.

21 Por. Apollodorus, Bibliotheca 1,1,6 (LCL 121, 7): „Rhea repaired to Crete, when she was big with Zeus, and brought him forth in a cave of Dicte”. Por. Hesiodus, Theogonia (Kaszewski, 473-483): „Oni zaś miłej córki próśb wysłuchali życzliwie, wyjawili jej także wszystko, co było sądzone Kronosowi królowi i jego dzielnemu synowi, i do Lyktos posłali, żyznej krainy na Krecie, gdy miała już na świat wydać najmłodsze z swych dzieci - Dzeusa wielkiego; a jego przyjęła Ziemia ogromna, by go wyżywić, a także wychować na Krecie rozległej. Tak więc, go niosąc, ruszyła poprzez noc szybką i czarną wpierw na Lyktos i skryła go, wziąwszy na ręce, w przepaścistej jaskini, w głębinach ziemi przeświętej, w górach Ajgajonu pokrytych leśną gęstwiną".

22 Callimachus, Hymnus ad Iovem (Steffen). 
Zygmunt Kubiak, cytując słowa Kallimacha o domniemanej śmierci Zeusa („«Łżą Kreteńczycy». Nawet grób ci sporządzili, Panie, a tyś nie umarł, żyjesz bowiem wiecznie”), nazywa je „antykreteńską inwektywą" ${ }^{23}$.

\section{Epimenides z Krety i kłamstwo jego rodaków w kontekście biblijnym}

Jan Chryzostom (IV/V w.) w trzeciej Homilii na List do Tytusa potwierdza, że słowa z Tt 1,12 pochodzą od Epimenidesa ${ }^{24}$. Następnie przywołuje przekonanie Kreteńczyków o tym, że na Krecie znajduje się grób rzymskiego boga Jowisza, utożsamianego z greckim Zeusem, czego potwierdzeniem ma być odpowiednia inskrypcja. Według Chryzostoma Epimenides wyśmiewa swoich rodaków i nazywa ich kłamcami za twierdzenie o posiadaniu grobu Zeusa. Powoduje to jednak problem, bo Paweł, cytując Epimenidesa, zgadza się z nim $(\mathrm{Tt} 1,13)$, przez co pośrednio aprobuje przekonanie Epimenidesa o nieśmiertelności Zeusa. Chryzostom wychodzi z tego impasu twierdząc, że Paweł w Tt 1,12 przywołuje tylko te słowa Epimenidesa, które odnoszą się do samego kłamania, nie zaś konkretnego kłamstwa dotyczącego śmierci Zeusa, pomimo tego, że oryginalnie słowa te miały właśnie do tego kłamstwa się odnosić. Chryzostom dalej twierdzi, że powoływanie się na pogańskiego proroka nie oznacza akceptacji go jako takiego, ale jest zabiegiem retorycznym, polegającym na cytowaniu autorów rdzennych odbiorcom.

Hieronim ze Strydonu (IV/V w.) identyfikuje proroka jako poetę Epimenidesa ${ }^{25}$, przy czym według niego określenie to należy rozumieć jako użyte w sposób szyderczy:

Podobno ów wiersz znajduje się w Wyroczniach kreteńskiego poety Epimenidesa, którego z szyderstwem nazwał prorokiem, ponieważ tacy chrześcijanie oczywiście na takich zasługują proroków. Prorokami byli: Baal, prorocy zamętu, inni prorocy zgorszeń i jakichkolwiek tylko proroków wspomina Pismo, czy to dlatego prawdziwie, ponieważ napisał z wyroczni i odpowiedzi, które właśnie zapowiadają przyszłość, i o wiele wcześniej zapowiadają to, co ma nadejść. W końcu sama księga nosi tytuł Wyrocznie, a ponieważ uznawano, że przyobiecuje coś boskiego, sądzę, że dlatego Apostoł zajrzał do niej, aby zobaczyć, co przyrzeka wróżbiarstwo pogańskie. Celowo posłużył się wierszem, pisząc do Tytusa, który

23 Kubiak, Mitologia, 137.

24 Iohannes Chrysostomus, In epistulam ad Titum, Homiliae III (NPNF XIII, 528) (tekst całej homilii znajduje się na s. 528-531). Do Tt 1,12 nawiązują także inni starożytni autorzy, por. Gorday, Ancient Christian Commentary on Scripture, 290-291 (Atenagoras, Atanazy, Teodoret z Cyru, Teodor z Mopsuestii).

25 Por. Hieronymus, Ep. XXXIV (NPNF² IV, 149). Hieronim twierdzi w tym liście, że Kallimach wykorzystał następnie tekst Epimenidesa (ibidem). 
był na Krecie, po to, aby pokonać fałszywych nauczycieli kreteńskich przy pomocy mędrca $\mathrm{z}$ ich własnej wyspy ${ }^{26}$.

Obok Epimenidesa Hieronim wspomina także o Kallimachu z Cyreny ${ }^{27}$, po czym przywołuje zarzut stawiany Pawłowi:

Niektórzy mniemają, że Apostoła należy zganić, ponieważ nieroztropnie pomylił się i karcąc fałszywych nauczycieli, potwierdził ów wiersz, ponieważ dlatego o Kreteńczykach mówią, że są oszustami, ponieważ zbudowali próżny grób Jowisza. Jeśli bowiem Epimenides lub Kallimach mówili, że dlatego Kreteńczycy są oszustami i gani ich jako «złe bestie i brzuchy leniwe», ponieważ nie mają poczucia rzeczy boskich i zmyślają, że Jowisz, który panuje w niebie, został pochowany na ich wyspie: i to co oni powiedzieli, jest potwierdzone zdaniem Apostoła, a wynika z tego, że Jowisz nie umarł, lecz żyje. W sposób niemądry przeto Paweł, burzyciel idolatrii, walcząc z przewrotnymi nauczycielami, potwierdził istnienie bogów, których zwalczał28.

Hieronim, próbując zmierzyć się z tym oskarżeniem, m.in. pisze:

Kallimach i Epimenides nie dlatego wyrazili rzeczy prawdziwe, że [powiedzieli, iż] Jowisz jest bogiem i pozostałe rzeczy zawarte w ich pieśniach, ponieważ Kreteńczycy są oszustami; lecz tylko w tym powiedzieli prawdę, że wyrazili przyrodzoną Kreteńczykom wadę, jaką jest kłamstwo, ale chociaż są oni oszustami, to nie znaczy, że czasem nie mówili prawdy. Ani bowiem dlatego Jowisz nie byłby bogiem, gdyby Kreteńczycy mówili prawdę, lecz nawet, gdyby milczeli, to ten, który zmarł, nie nosiłby imienia boga ${ }^{29}$.

Jeżeli Kreteńczycy kłamią, to znaczy, że Jowisz żyje i jego grób na Krecie nie ma znaczenia. Jeśli zaś mówią prawdę, to oznacza, że Jowisz rzeczywiście umarł i jest pochowany na Krecie. Skoro Paweł twierdzi, że Kreteńczycy kłamią, to znaczy, że Jowisz nigdy nie umarł i jest bogiem. Hieronim próbuje ratować autora Tt 1,12 z jednej strony w ten sposób, że twierdzi, iż Paweł nie odwołuje się do oryginalnego kontekstu powiedzenia Epimenidesa, lecz jedynie do ogólnej przywary przypisanej Kreteńczykom, z drugiej zaś - poprzez odwołanie się do Tt 1,13, który według niego ma wskazywać, że Paweł sygnalizuje, że nie zgadza się z całym tekstem Epimenidesa:

W końcu abyśmy wiedzieli, że Apostoł nieprzypadkowo, i jak się chce [rzec] mimowolnie (jak oni sądzą), lecz z rozmysłem i rozważnie, z każdej strony zabezpieczają się, powie-

\footnotetext{
Ambrosius, Hieronymus, Pelagius, Commentariorum (Baron, 149). Por. Kobyłka et al., Komentarz, 149n.

Kobyłka et al., Komentarz, 150-151.

Kobyłka et al., Komentarz, 151.

Kobyłka et al., Komentarz.
} 


\section{PIOTR LOREK}

dział: (1, 13A) Świadectwo, mówi, to jest prawdziwe; nie cała pieśń, z której świadectwo jest wzięte, nie całe dzieło, lecz tylko to świadectwo, ten wiersz, w którym są nazwani kłamcami. W każdym razie jest oczywiste, że ten, który tylko z jedną częścią poematu się zgadza, pozostałe odrzuca ${ }^{30}$.

Powyższa obrona Hieronima przed „lekkomyślnością” Pawła prowadzi do wniosku o tym, że autor Tt 1,12 wyciąga słowa Epimenidesa $\mathrm{z}$ ich oryginalnego kontekstu. W ten sposób czyni z tych słów ogólną inwektywę wymierzoną przeciw Kreteńczykom, a następnie wykorzystuje ją we własnej dyskusji, zupełnie nie związanej z kwestią grobu Zeusa ${ }^{31}$.

W nowotestamentowym kontekście oskarżenie ma dotyczyć Kreteńczyków, głównie żydowskiego pochodzenia (Tt 1,10; por. 1,14), mających kłamać dla „niegodziwego zysku” (Tt 1,11; BW) poprzez „żydowskie baśnie” i „nakazy ludzi” (Tt 1,14; BW), zapewne dotyczące także konieczności zachowania czystości (Tt 1,15). Swoim zachowaniem odwracają się od „prawdy” (Tt 1,14), która m.in. dotyczy „nadziei żywota wiecznego” (por. Tt 1,1-2). W tym kontekście inwektywy „wstrętne bydlęta” oraz „brzuchy leniwe” z Tt 1,12 nie będą związane z kultem Zeusa, ale z niemoralnym postępowaniem ${ }^{32}$.

\section{Epimenides z Krety i Areopag w kontekście biblijnym}

Zauważmy, już tylko skrótowo, że postać Epimenidesa zdaje się być obecna nie tylko Tt 1,12, ale również i w Dz 17,28. Diogenes Laertios, jak cytowaliśmy powyżej, wspomina o Epimenidesie, który dokonał oczyszczenia Aten poprzez składanie nieznanym bogom ofiar z owiec. Ofiary były składane w miejscach, w których owce kładły się przepędzone ze wzgórza Areopagu ${ }^{33}$. Z tegoż to powodu, jak twierdzi Diogenes, pojawiły się „bezimienne ołtarze po wsiach attyckich”. Opis ten zdaje się nawiązywać do historii Pawła z Dz 17, który wstrząśnięty bałwochwalstwem na wzgórzu Areo-

30 Kobyłka et al., Komentarz, 152.

31 Teodoret z Cyru (Ad Romanos, ŹMT 20, 187) znajduje jeszcze inne rozwiązanie. Kreteńczycy są kłamcami być może dla tego, że „tak zwany Zeus umarł gdzie indziej, a oni lekkomyślnie usypali mu grób”. Ambrozjaster nie identyfikuje proroka z Tt 1,12 jako Epimenidesa, stąd w jego rozważaniach nie pojawia się problem $\mathrm{z}$ akceptacją stwierdzenia Epimenidesa przez Pawła, a więc pośrednio z dopuszczeniem myśli o nieśmiertelności Zeusa. Ambrosius, Hieronymus, Pelagius, Commentariorum (Baron, 113). Por. też rozważania Orygenesa odnośnie do grobu Zeusa w świetle krytyki Celsusa w Origenes, Contra Celsus III, 43 (Kalinkowski, 163).

32 Riemer Faber („Evil Beasts, Lazy Gluttons”, 135-145) daje próbkę tego, jak cytat z Tt 1,12 wpisuje się w tematykę całego listu. Kontekstualne odczytanie cytatu ukazuje, jak jego możliwe pierwotne znaczenie ginie w nowym, nowotestamentowym kontekście.

33 Por. podobnie w: Barclay, Dzieje Apostolskie, 201. 
pagu wspomina o ołtarzu poświęconemu nieznanemu bogu i - podobnie jak Epimenides - chce oczyścić to miejsce (Paweł z bałwochwalstwa, Epimenides z zarazy). Ponadto w mowie Pawła na Areopagu (Dz 17,28a) padają z jego ust słowa: „w nim żyjemy i poruszamy się, i jesteśmy", które zgodnie z rekonstrukcją Harrisa, mają pochodzić właśnie od Epimenidesa, i to z fragmentu, w którym mamy (omówione powyżej) nawiązanie do kłamstwa Kreteńczyków. Frederick F. Bruce twierdzi, że te słowa, choć przypisywane Epimenidesowi, pochodzą od Teodora z Mopswestii ${ }^{34}$. W oryginalnym kontekście słowa z Dz 17,28a dotyczą nie Boga biblijnego, głoszonego przez Pawła na Areopagu, ale Zeusa ${ }^{35}$. Występują one w sąsiedztwie Epimenidesowego zapewnienia, o tym, że Kreteńczycy kłamią mówiąc o śmierci Zeusa, przez co podważają jego boskość. W przypadku mowy Pawła na Areopagu słowa Epimenidesa są przenoszone z Zeusa na Jahwe ${ }^{36}$.

\section{Zakończenie}

Podsumowując, należy zauważyć, że autorzy NT dwukrotnie nawiązują do fragmentu z dzieła Epimenidesa. W obu przypadkach bazują na uznanym przez lokalne środowiska autorytecie wieszcza, znanego zarówno Ateńczykom (Dz), jak i Kreteńczykom (Tt), korzystają z jego słów, jednakże wyłączając ich znaczenie z treści oryginalnego kontekstu. W przypadku Tt 1,12 nawiązanie do kłamstwa Kreteńczyków odnośnie do śmierci Zeusa staje się kłamstwem dotyczącym zbawiennej ważności judaistycznych praktyk religijnych dla zysku. W przypadku Dz 17,28a nawiązanie do bycia $\mathrm{w}$ greckim Zeusie zostaje przeformułowane i teraz ma dotyczyć bycia w Bogu żydowskim. Widać więc, że autorzy NT wykorzystują renomę proroka Epimenidesa dla własnych celów, nie uwzględniając pierwotnych konotacji jego słów.

34 Bruce, The Book of the Acts, 338-339. Sławomir Stasiak (Komentarz, 174) twierdzi, że Dz 17,28a „jest własnym stwierdzeniem Pawła”. Joseph A. Fitzmyer (The Acts, 610) uważa podobnie. James D.G. Dunn (The Acts, 236) przypisuje słowa z Dz 17,28a nieznanemu poecie greckiemu. Por. szerszą dyskusję w Barrett, A Critical and Exegetical Commentary, 846-848.

35 Por. Witherington III, The Acts, 529-530: "It may be that the first assertion [chodzi o Dz 17,28a, PL] goes back to words originally addressed to Zeus in a poem attributed to the Cretan poet Epimenides, another part of which is quoted at Titus 1:12. We do not have the original poem, however, and there are similar assertions by pagans (see Dio, Or. 12.43)".

36 Dodajmy dla porządku, że Chryzostom w swoich homiliach opartych o Dzieje Apostolskie 17 nie wspomina o Epimenidesie (Homilie XXXXVII-XXXIX), a Hieronim w swoich pismach nie przywołuje Epimenidesa przy okazji nawiązań do Dz 17. Por. Iohannes Chrysostomus, In Acta apostolorum, Homilies (NPNF $F^{1}$ XI, 228-244). Por. Hieronymus, Ep. XXXIV, Ep. LXX oraz Against Jovinianus. 


\section{PIOTR LOREK}

\section{Bibliografia}

Ambrosius, Hieronymus, Pelagius, Commentariorum In Epistolam Beati Pauli ad Titum, tł. pol. A. Baron: Ambrozjaster, Hieronim, Pelagiusz, Komentarze do Listu św. Pawła do Tytusa (Kraków: Wydawnictwo WAM 2003).

Apollodorus, Bibliotheca: Apollodorus, The Library. I. Books 1-3.9 (tł. J.G. Frazer) (Loeb Classical Library 121; Cambridge, MA: Harvard University Press - London: Heinemann 1921).

Aristotelis, Ars Rhetorica - Rhetorica ad Alexandrum - Ars Poetica, tł. pol. H. Podbielski: Arystoteles, Retoryka - Retoryka dla Aleksandra - Poetyka (Warszawa: Wydawnictwo Naukowe PWN 2008).

Aristotelis, Atheniensium Respublica, tł. pol. L. Piotrowicz: Arystoteles, Ustrój polityczny Aten (Warszawa: Państwowe Wydawnictwo Naukowe 1973).

Barclay, W., Dzieje Apostolskie (Warszawa: Słowo Prawdy 1979).

Barrett, C.K., A Critical and Exegetical Commentary of the Acts of the Apostles (Edinburgh: Clark 1998) II.

Bruce, F.F., The Book of the Acts, wyd. poprawione (Grand Rapids, MI: Eerdmans 1988).

Clemens Alexandrinus, Stromata, tł. pol. J. Niemirska-Pliszczyńska: Klemens Aleksandryjski, Kobierce zapisków filozoficznych dotyczacych prawdziwej wiedzy (Warszawa: Instytut Wydawniczy PAX 1994).

Collins, R.F., I \& II Timothy and Titus. A Commentary (Louisville, KY: Westminster John Knox 2002).

Dąbrowski, E., „Cytaty z Aratosa i Epimenidesa w mowie na Areopagu”, E. Dąbrowski, Dzieje Apostolskie. Wstęp - przekład z oryginału - komentarz (Poznań: Pallottinum 1961) 542-549.

Diogenis Laertii, De Vitis, Dogmati et Apophthegmatis Clarorum Philosophorum, tł. pol. I. Krońska: Diogenes Laertios, Żywoty i poglądy stynnych filozofów (Warszawa: Państwowe Wydawnictwo Naukowe 1968).

Dunn, J.D.G., The Acts of the Apostles (Valley Forge, PA: Trinity Press International 1996).

Faber, R., "Evil Beasts, Lazy Gluttons': A Neglected Theme in the Epistle to Titus”, Westminster Theological Journal 67 (2005) 135-145.

Fee, G.D., 1 and 2 Timothy, Titus (Peabody, MA: Hendrickson 1993).

Fitzmyer, J.A., The Acts of the Apostles. A New Translation with Introduction and Commentary (Anchor Bible 31; New York: Doubleday 1998).

Gorday, P. (red.), Ancient Christian Commentary on Scripture (Downers Grove, IL: InterVarsity 2000) IX.

Harris, J.R., "A Further Note on the Cretans", The Expositor seventh series 3/4 (1907) 332-337.

Harris, J.R., "St. Paul and Epimenides", The Expositor eighth series 4/4 (1912) 348-353.

Harris, J.R., “The Cretans Always Liars”, The Expositor seventh series 2/4 (1906) 305-317.

Hesiodus, Theogonia, tł. pol. K. Kaszewski: Hezjod, Teogonia (Sandomierz: Armoryka 2010).

Hieronymus, Epistulae: Jerome, Nicene and Post-Nicene Fathers. Second Series. VI. Letters and Select Works (red. P. Shaff) (Peabody, MA: Hendrickson 2012).

Iohannes Chrysostomus, In Acta apostolorum: Jan Chryzostom, „Homilies on the Acts of the Apostles", Nicene and Post-Nicene Fathers, First Series. XI. Homilies of the Acts of the Apostles and the Epistle to the Romans (red. Ph. Shaff) (Buffalo, NY: Christian Literature Publishing 1889). 
Iohannes Chrysostomus, In epistulam ad Titum: Jan Chryzostom, From Nicene and Post-Nicene Fathers, First Series. XIII. Homily III on Titus i. 12-14 (red. Ph. Schaff) (Buffalo, NY: Christian Literature Publishing 1889).

Kalinowski, D., „Dlaczego Jezus cytował Pawłowi na drodze do Damaszku greckich poetów”, http://acalyludpowieamen.pl/dlaczego-jezus-cytowal-pawlowi-na-drodze-do-damaszku-greckich-poetow/ [dostęp: 21.06.2021].

Kallimach z Cyreny, Hymn o Zeusie (tł. W. Steffen) http://pantheion.pl/Kallimach-Hymn-o-Zeusie [dostęp: 21.06.2021].

Keener, C.S., The IVP Bible Background Commentary. New Testament (Downers Grove, IL: InterVarsity 1993).

Kobyłka, J.J. et al., Komentarz do 1-2 Listu do Tymoteusza, Listu do Tytusa, Listu do Filemona i Listu do Hebrajczyków (Komentarz Teologiczno-Pastoralny do Biblii Tysiąclecia. Nowy Testament 4; Poznań: Pallottinum 2015).

Krause, M.S., "Crete”, The Lexham Bible Dictionary (red. J.D. Barry et al.) (Bellingham, WA: Lexham 2016).

Kubiak, Z., Mitologia Greków i Rzymian (Warszawa: Świat Książki 1997).

Origenes, Contra Celsus, tł. pol. S. Kalinkowski: Orygenes, Przeciw Celsusowi, wyd. 2 (Warszawa: Akademia Teologii Katolickiej 1986).

Plato, De Legibus, tł. pol. M. Maykowska: Platon, Prawa, wyd. 2 (opr. M. Maykowska) (Warszawa: ALFA 1997).

Plutarchus Chaeroneus, Vitae parallelae, tł. pol. M. Brożek: Plutarch z Cheronei, Żywoty sławnych mężów (Z żywotów równoległych) (Wrocław - Warszawa - Kraków: Ossolineum 1996).

Quinn, J.D., The Letter to Titus (New York: Doubleday 1990).

Stasiak, S., Komentarz do Dziejów Apostolskich, Listu do Rzymian, 1-2 Listu do Koryntian i Listu do Galatów (Komentarz Teologiczno-Pastoralny do Biblii Tysiąclecia. Nowy Testament 2; Poznań: Pallottinum 2014).

Strabo, Geographica, tł. pol. E. Kaczyńska - K.T. Witczak: Strabon, „Opis Krety (Geographica X.4,1-5)", Meander 51/3-4 (1996) 223-232.

Theodoretus Cyrensis, Interpretatio in XII epistulas s. Pauli. Ad Romanos, tł. pol. S. Kalinkowski: Teodoret z Cyru, Komentarz do listów Pawłowych do Tesaloniczan, Tymoteusza, Tytusa, Filemona i hebrajczyków (Źródła Myśli Teologicznej 20; Kraków: Wydawnictwo WAM 2001).

Witherington III, B., The Acts of the Apostles. A Socio-Rhetorical Commentary (Grand Rapids, MI - Cambridge, U.K.: Eerdmans 1998). 
